\title{
Place of residence as a factor differentiating physical activity in the life style of Ukrainian students
}

\author{
Józef Bergier', Barbara Bergier', Anatolii Tsos ${ }^{1,2}$ \\ ${ }^{1}$ Pope John Paul II State School of Higher Education, Biała Podlaska, Poland \\ ${ }^{2}$ Lesya Ukrainka Eastern European National University, Lutsk, Ukraine
}

Bergier J, Bergier B, Tsos A. Place of residence as a factor differentiating physical activity in the life style of Ukrainian students. Ann Agric Environ Med. 2016; 23(4): 549-552. doi: 10.5604/12321966.1226844

\begin{abstract}
Determining the state of physical activity of societies as an important component of a health promoting life style is a very up-to-date problem. Studies of physical activity among students, the future elites in their environments, become of increasing importance. An important problem is the recognition of factors differentiating this activity on the example of place of residence. For this purpose, the study covered 2,125 students (60.8\% females and 39.2\% males) from the National Institute in Lutsk, Ukraine, aged 17-22 (mean age: 20.4). The method of a diagnostic survey was applied which included the International Physical Activity Questionnaire (IPAQ). The following measures of physical activity according to the place of residence (rural area, small town with a population up to 100,000; medium-size town - 100,000-200,000 inhabitants; large city - over 200,000) were taken into consideration: level of physical activity, self-reported physical fitness, sports disciplines practiced by the respondents, and those which they would like to practice, and the BMI, and leisure time possessed. The study showed that the place of residence positively differentiated physical activity among students from medium-size towns and rural areas, compared to their contemporaries from small towns and large cities. Significant differences were also found with respect to the BMI, which was significantly less favourable among respondents from the rural environment. However, no differences were observed between the place of residence for leisure time, self-reported physical activity, and forms of physical activity practiced, and those which the respondents would like to practice.
\end{abstract}

Key words

physical activity, IPAQ, place of residence.

\section{INTRODUCTION}

Physical activity occupies an important position in prophylactic actions on behalf of human health $[1,2,3]$. Systematic physical activity reduces the risk of many diseases, especially cardiovascular diseases, diabetes and obesity $[4,5]$. In order to perform an objective measurement of physical activity, efforts were undertaken at the beginning of this century to develop the International Physical Activity Questionnaire [6]. This instrument was used in many countries $[7,8,9,10]$ to be implemented for common studies. Studies carried out among students have also found their place in the assessment of physical activity of various social groups $[8,11,12,13]$. The international rank of the IPAQ questionnaire is best evidenced by the fact of its validation in many countries worldwide $[14,15,16,17]$.

\section{OBJECTIVE}

The aim of the research was to establish a link between the level of physical activity and place of residence, and such factors as fields of physical activity, leisure time, fitness selfassessment, the sports the person has been performing or they would like to perform, and the BMI.

Address for correspondence: Józef Bergier, Pope John Paul II State School of Higher Education, Sidorska 95/97, 21-500 Biała Podlaska, Poland

E-mail: p.rynkiewicz@pswbp.pl

Received: 13 April 2015; accepted: 30 June 2015

\section{MATERIALS AND METHOD}

The research was conducted in 2013, on a group of 2,125 students from 12 majors at the University of Lutsk, Ukraine, in the 12-22 age bracket, including 1,291 females (60.8\%) and 834 males (39.2\%). When assessing the physical activity, the long version of IPAQ was used, supplemented with 3 original questions by the authors.

\section{RESULTS}

The following areas of the student's physical activity were considered: leisure time, level of physical activity and its areas, self-reported physical fitness, number of sports disciplines practiced and those which the students would like to practice, and the BMI.

Place of residence and areas of physical activity. Place of residence significantly differentiated the respondents' physical activity measured by the IPAQ. The highest level of total physical activity (4.034 MET) was observed among students from medium-size towns. Their level of total activity was significantly higher than that of students from small towns and large cities. Students from the rural environment occupied the second position according to physical activity - 3.861 MET, which was also significantly higher compared to their contemporaries from small towns (3.433 MET) and large cities (3.245 MET) (Fig. 1). 


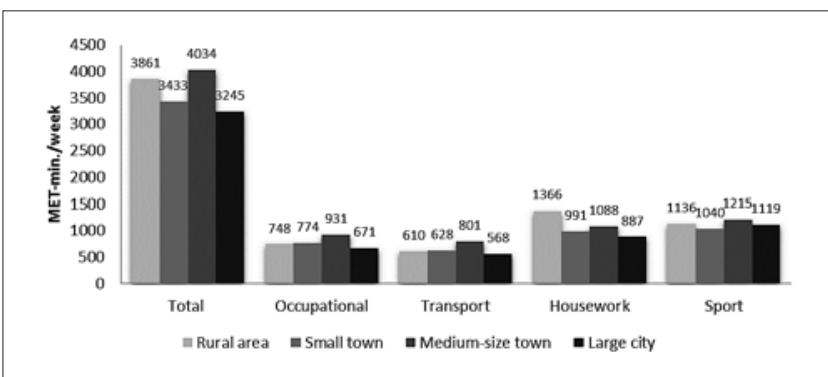

Figure 1. Areas of students' physical activity according to place of residence

Significant differences were found in 3 out of 4 domains of activity. With respect to transport activity, the highest value was noted among students from medium-size towns (801 MET) and rural areas (610 MET), who significantly differed from their contemporaries living in large cities (568 MET).

Considering activities related with household chores, students from the rural areas obtained the highest results (1.366 MET), and significantly differed from their contemporaries from other environments (Tab.1). In this domain, students from medium-size towns obtained significantly higher values (1.088 MET) than inhabitants of large cities (887 MET).

Table 1. Differences in areas of students' physical activity according to place of residence

\begin{tabular}{lccc}
\hline Kruskal-Wallis test & & & \\
\hline Area of activity & $\mathrm{H}$ & $\mathrm{p}$ & Significant Pairwise DifferencesA \\
\hline Total & 38.03319 & $<0.0001$ & $1-2,4 ; 2-3 ; 3-4$ \\
\hline Occupational & 1.779485 & 0.6194 & - \\
\hline Transport & 30.95871 & $<0.0001$ & $1-4 ; 3-4$ \\
\hline Household & 73.18911 & $<0.0001$ & $1-2,3,4 ; 3-4$ \\
\hline Sport & 11.92369 & 0.0076 & $2-3$ \\
\hline
\end{tabular}

A - Differences at $p<0.05$

Numbers for places of residence:

1 - Rural area; 2 - Small town; 3 - Medium-size town; 4 - Large city.

With respect to sports-recreation activities at students' disposal during leisure time, the highest indicator of activity was also found among respondents from medium-size towns (1.215 MET), this activity being significantly higher compared to their colleagues from small towns (1.040 MET).

Place of residence and self-reported physical fitness. No significant differences were observed between groups of respondents from the examined environments. It is noteworthy that the lowest percentage of rural adolescents evaluated their physical fitness as low $-13.7 \%$, whereas the highest percentage of students from large cities evaluated this activity as high $-15.9 \%$ (Fig. 2).

Place of residence and number of sports disciplines practiced. No significant differences in the number of sports disciplines practiced were observed according to the place of residence. The percentages of practiced disciplines were nearly identical for each group of residence. A positive phenomenon was only a trace percentage of not practicing any sports discipline (Fig. 3).

Place of residence and number of sports disciplines which the students would like to practice. Also in this

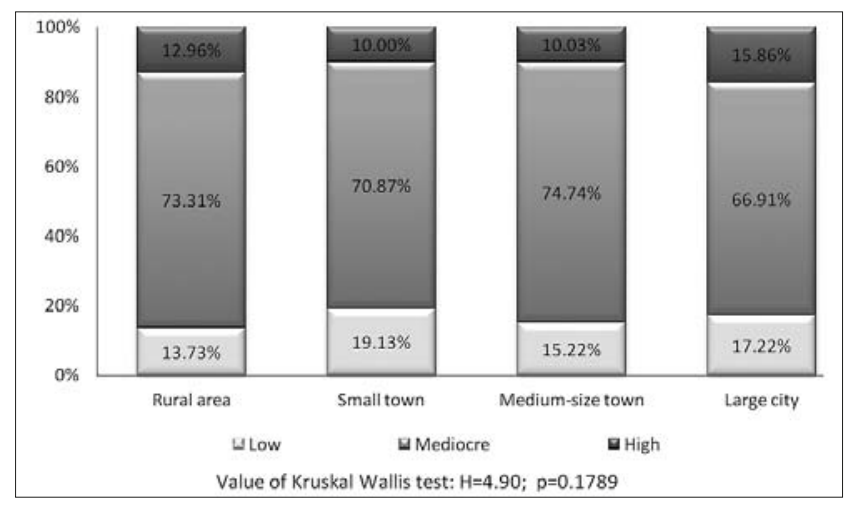

Figure 2. Students' self-reported physical fitness according to place of residence

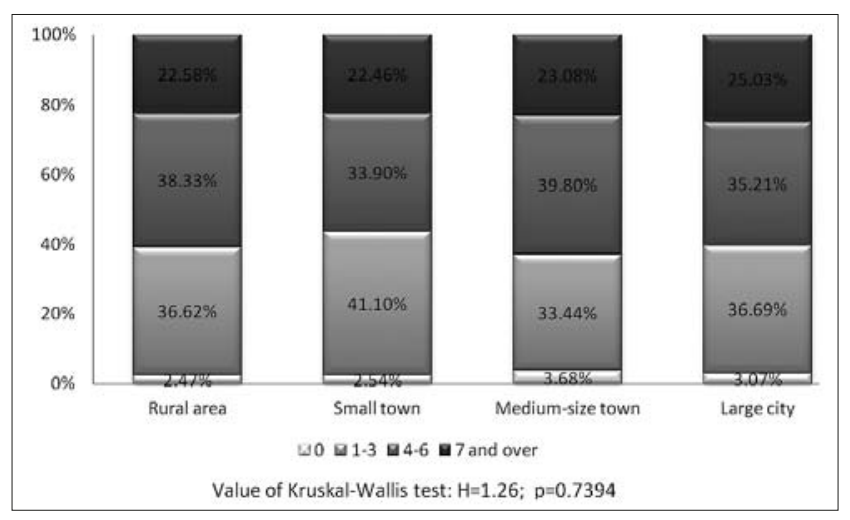

Figure 3. Number of sports disciplines practiced by students, according to place of residence

compilation, no differences in an interest in new sports disciplines were found according to the respondents' place of residence. Students from the rural environment were characterized by the highest percentage of the 3 and more sports disciplines practiced $-40.0 \%$, and the lowest with respect to not practicing new disciplines $-20.7 \%$ (Fig. 4).

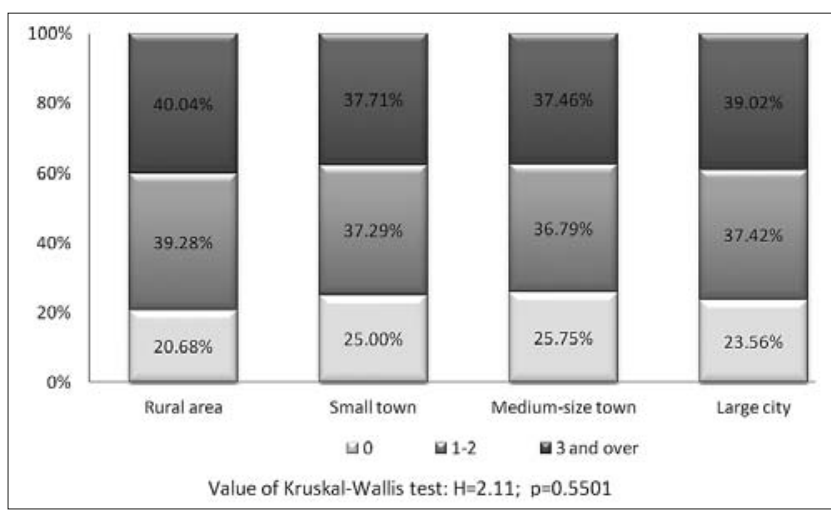

Figure 4. Number of sport disciplines which students would like to practice, according to place of residence

** - Numbers of places of residence between which a significant difference $(p<0.05)$ was observed

Place of residence and BMI. In concern for our health, apart from physical activity, the BMI also occupies an important position. The BMI significantly differentiated the examined environments, and was significantly less favourable for respondents from the rural environment, compared to each of the remaining groups (Fig. 5). 


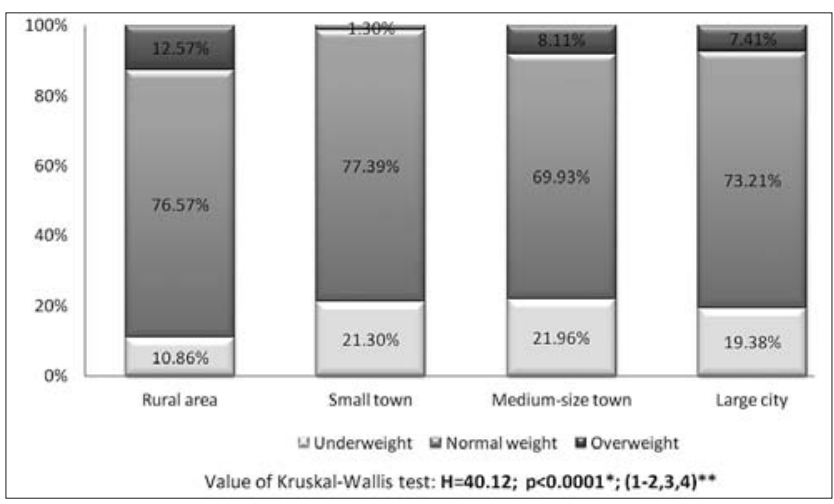

Figure 5. Students' BMI classification, according to place of residence

Place of residence and scope of leisure time. No significant differences were noted in the scope of leisure time according to the students' place of residence. Attention should be paid to the fact that rural adolescents were characterized by the lowest percentage of leisure time at their disposal $-8.1 \%$ of respondents, this percentage being the highest among students from medium-size towns who had a sufficient amount of leisure time (Fig. 6).

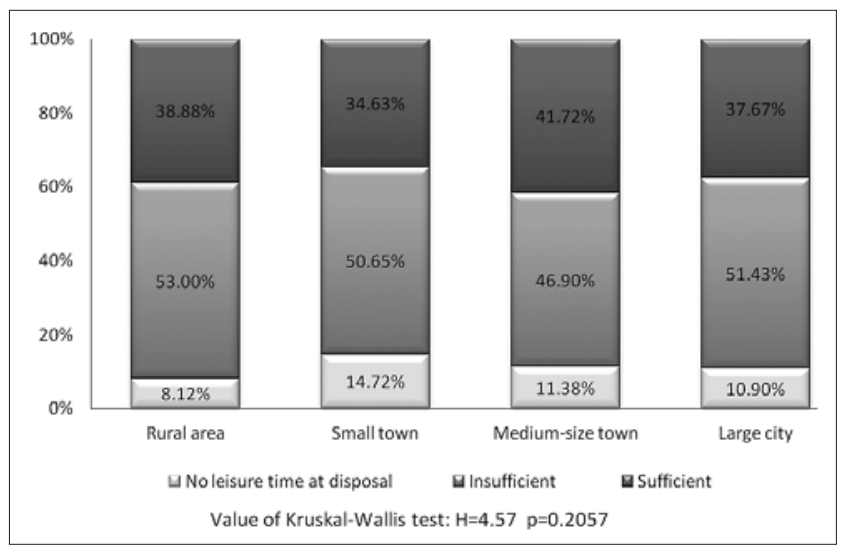

Figure 6. Scopes of leisure time at respondents' disposal, according to place of residence

\section{DISCUSSION}

An increasingly more intensive mode of life of modern societies requires taking care of leisure time at our disposal, which may create an opportunity for developing own interests, including active forms of leisure. The minority of students from Ukraine (37.7\%) declared that they had a sufficient amount of free time. In the case of students from Poland, this percentage was higher $-63.4 \%$ of males, and $48.9 \%$ of females [18]. An even smaller amount of leisure time characterized respondents who were occupationally active, and nurses - only $12.2 \%$ [19]. It is noteworthy that among the students in the study, the place of residence was not the factor significantly differentiating the possession of leisure time.

Differences in students' physical activity were observed according to their place of residence. The highest level of this activity concerned students living in medium-size towns and rural areas, and was significantly higher than that among their contemporaries from small towns and large cities. It also is noteworthy that all-Polish studies conducted among school adolescents and university students in Poland showed that the highest percentage of young people with a low physical activity lived in the rural environment [13]. Additionally, no significant differences were found according to self-reported physical fitness, and the lowest percentage of students from rural areas evaluated their fitness as low.

The number of sports disciplines practiced for recreation may also evidence the physical activity of society. In the case of students from Ukraine, no differences in the number of disciples practiced were found according to the place of residence. Similarly, no significant differences were observed with respect to practicing new forms of motor activity by students from various places of residence.

In concern for our health, apart from regularly practiced physical activity, the BMI occupies an important position. The majority of students from Ukraine were characterized by normal values of this index, similar to the data concerning students in Turkey [20] and Poland [21]. However, it should be noted that the BMI value was significantly higher among adolescents from the rural environment. Other European studies confirm the phenomenon of higher obesity and overweight among the rural population $[22,23]$.

According to the World Health Organization, in 2015, the number of overweight population will be 1.6 billion, and those obese -700 million. Polish studies demonstrate that this problem also concerns university students $[24,25]$. Summing up the analysis of health behaviours of students from Ukraine according to the place of residence, it should be presumed that there emerges a levelling of the differences according to the place of residence. This regularity concerns the possession of leisure time, level of physical activity, forms of physical activity practiced and expected, and self-reported physical fitness. However, the phenomenon of less favourable parameters related with obesity and overweight becomes established to the detriment of university students from the rural environment.

\section{CONCLUSIONS}

As a result of research on factors differentiating physical activity of Ukrainian students according to the place of residence, the following conclusions were formulated:

1. Significant differences in students' physical activity were found according to the place of residence, this activity being the highest among inhabitants of medium size towns and rural areas.

2. In the sphere of activity related with household chores, students from the rural environment were characterized by significantly higher values than those from other environments.

3. No significant differences in the level of physical activity were observed with respect to self-reported fitness and number of sports disciplines practiced, as well as those in which the students would like to participate.

4. Significant differences in the BMI were noted according to the place of residence, its values being the highest in the rural environment, which is unfavourable for the students' health. 


\section{REFERENCES}

1. Chen X, Sekine M, Hamanishi SM, Wang H, Hayashikawa Y, Yamagami $\mathrm{T}$, et al. The validity of nursery teachers report on the physical activity of Young children. J Epidemiol. 2002; 12: 367-374.

2. Craig CL, Marshall AL, Sjostrom M, Bauman AE, Booth ML, Ainsworth BE, Pratt M, Ekelund U, Yngve A, Sallis JF, Oja P. International Physical Questionnaire: 12-country reliability and validity. Med Sci Sport Exerc. 2003; 35: 1381-1395.

3. Andersen LB, Harro M, Sardinha LB. Physical activity and clustered cardiovascular risk in children: a cross-sectional study (The European Youth Heart Study). Lancet 2006; 368(9532): 299-304.

4. Schnohr P, Kristensen TS, Prescott E, Scharling H. Stress and life dissatisfaction are inversely associated with jogging and other types of physical activity-The Copenhagen City Heart Study. Scand J Med Sci Sports. 2005; 15(2): 107-112.

5. Grant N, Wardle J, Steptoe A. The relationship between life satisfaction and health behaviour: a cross-cultural analysis of young adults. IJBM 2009; 16: 259-268.

6. Booth ML. Assessment of Physical Activity: An International Perspective. Res Quart Exerc Sport. 2000; 71: 114-20.

7. Ainsworth BE, Macera CA, Jones DA, Reis JP, Addy CL, Bowles HR, et al. Comparison of the 2001 BRFSS and the IPAQ Physical Activity Questionnaires. Med Sci Sports Exerc. 2006; 38 (9): 1584-1592.

8. Biernat E. Aktywność fizyczna mieszkańców Warszawy na przykładzie wybranych grup zawodowych. Oficyna Wydawnicza. Szkoła Główna Handlowa w Warszawie. Warszawa 2011.

9. Hallal PC, et al. Physical activity: prevalence and associated variables in Brazilian adults. Med Sci Sport Exerc. 2003; 35: 1894-1900.

10. Roman-Vinas B, Serra-Majem L, Hagstromer M, Ribas-Barba L, Sjostrom M, Segura-Cardona R. International Activity Questionnaire: Reliability and validity in a Spanish population. Eur J Sport Sci. 2010; 10(5): 297-304.

11. Mynarski W, et al. Aerobic Capacity of studenst with Different Levels of Physical Activity as Assessed by IPAQ. J Hum Kinet. 2009; 21: 89-96.

12. Niźnikowska E, Bergier J, Bergier B, Stępień E. The year of study and the physical activity of students of selected fields of study at State School of Higher Education in Biala Podlaska. Central Eur J Sport Sci Med. 2014; 6(2): 67-75.

13. Bergier J, Kapka-Skrzypczak L, Bilinski P, Paprzycki P, Wojtyła A. Physical activity of Polish adolescents and young adults according to IPAQ: a population based study. Ann Agric Environ Med. 2012; 19(1): 109-115.
14. Sigmund E, Frömel K. Sallis. F. The Reliability of the Long and Short IPAQ Forms in Czech Youth aged 15-24y. Med Sci Sports Exercise 2007; 39: 191.

15. Zabina HY, Schmid TL, Potemkina RA, Glasunov IS, Deev AA. Evaluation of physical activity levels in Russia based on the international physical activity questionnaire (IPAQ). Med Sci Sports Exercise 2002; 34: 264.

16. Crinière L, Lhommet C, Lecomte P, Couet C, Oppert JM, Jacobi D. Validation du IPAQ français version longue chez les personnes diabétiques, Diabetes Metab. 2009; Suppl. 1(35): 50.

17. Ekelund U, Sepp H, Brage S, Becker W, Jakes R, Hennings M, Wareham NJ. Criterion-related validity of the last 7-day, short form of the International Physical Activity Questionnaire in Swedish adults. Pub Health Nutr. 2006; 9(2): 258-265.

18. Ignatjeva A, Bergier J. Nutritional habits and physical activity of the youth of Latvia considering gender differences. Health Problems of Civilization 2016, Vol. 10, Iss. 2: 25-34.

19. Ács P, Bergier J, Salonna F, Junger J, Melczer C, Makai A. Gender differences in physical activity among secondary school students in the visegrad countries (V4). Health Problems of Civilization 2016; 10(3): 21-29.

20. Tasmektepligil MY, Agaoglu SM, Atan T, Cicek G. The contrastive study of physical activity levels of physical education students and the other department students. Int J Acad Res. 2013; 5(6): 90-95.

21. Mynarski W, Rozpara M, Królikowska B, Puciato D, Graczykowska B. Jakościowe i ilościowe aspekty aktywności fizycznej. Studia i Monografie 2012; Zeszyt 313. Politechnika Opolska (in Polish).

22. Cea-Calvo L, Moreno B, Gil-Guillen V, Lozano JV, Marti-Canales JC, Listerri JL, Aznar J, Gonzales-Esteban J, Redon J. Prevalence and related factors of overweight and obesity in Spanish population aged 60 years - old and older. The PREV-ICTUS Study Med Clin. 2008; 131: 105-110.

23. Barbagallo CM, Cavera G, Sapienza M, Noto D, Cefalu AB, Polizzi F, Onorato E, Rini GB, Di Fede G, Pagano M, Montalto G, Rizzo M, Descowich GC, Notabartolo A, Averna MR. Nutritional characteristics of a rural southern Italy population. The Ventimiglia di Sicilia Project. J Am Coll Nut. 2002; 21(5): 523-529.

24. Rębacz-Maron E, Pawlak M, Michnik K. Stan odżywienia i aktywność fizyczna wśród studentek Uniwersytetu Szczecińskiego. Probl Hig Epidemiol. 2013; 94(2): 371-377 (in Polish).

25. Romanowska- Tołłoczko A. Styl życia studentów oceniany w kontekście zachowań zdrowotnych. Hygeia Pub Health 2011; 46(1): 89-93 (in Polish). 